\title{
Excessive Bruising
}

National Cancer Institute

\section{Source}

National Cancer Institute. Excessive Bruising. NCI Thesaurus. Code C113743.

Bruising that is disproportionately high to the amount of trauma received or reported. 